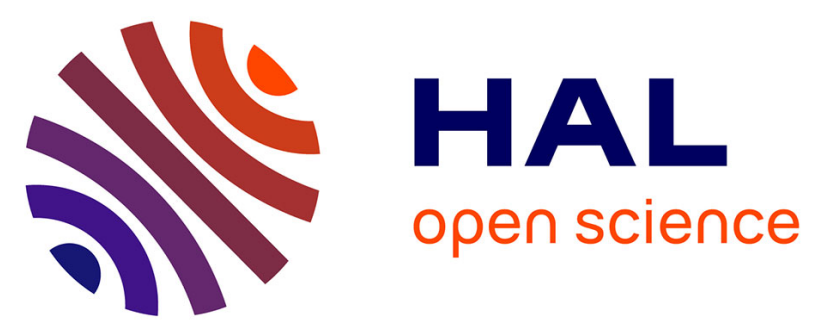

\title{
Optimal direct electron transfer between MWCNTs@COOH/BOD/chitosan layer and porous carbon felt for dioxygen reduction
}

Thi Xuan Huong Le, Valérie Flaud, Mikhael Bechelany, Marc Cretin, Sophie Tingry

\section{To cite this version:}

Thi Xuan Huong Le, Valérie Flaud, Mikhael Bechelany, Marc Cretin, Sophie Tingry. Optimal direct electron transfer between MWCNTs@COOH/BOD/chitosan layer and porous carbon felt for dioxygen reduction. Electrochimica Acta, 2017, 230, pp.373 - 381. 10.1016/j.electacta.2017.01.196 . hal01671753

\section{HAL Id: hal-01671753 \\ https://hal.umontpellier.fr/hal-01671753}

Submitted on 10 Jun 2021

HAL is a multi-disciplinary open access archive for the deposit and dissemination of scientific research documents, whether they are published or not. The documents may come from teaching and research institutions in France or abroad, or from public or private research centers.
L'archive ouverte pluridisciplinaire HAL, est destinée au dépôt et à la diffusion de documents scientifiques de niveau recherche, publiés ou non, émanant des établissements d'enseignement et de recherche français ou étrangers, des laboratoires publics ou privés. 


\title{
Optimal direct electron transfer between MWCNTs@COOH/BOD /chitosan layer and porous carbon felt for dioxygen reduction
}

\author{
Thi Xuan Huong Le ${ }^{\mathrm{a}, \mathrm{b}}$, Valérie Flaud ${ }^{\mathrm{c}}$, Mikhael Bechelany ${ }^{\mathrm{a}^{*}}$, Marc Cretin ${ }^{\mathrm{a}}$, Sophie Tingry ${ }^{\mathrm{a}^{*}}$ \\ a. IEM (Institut Europeen des Membranes), UMR 5635 (CNRS-ENSCM-UM), Universite de \\ Montpellier, Place E. Bataillon, F- 34095, Montpellier, France. \\ ${ }^{b}$ Van Lang University, 45 Nguyen Khac Nhu, District 1, Ho Chi Minh City, Viet Nam. \\ ${ }^{c}$ ICGM (Institut Charles Gerhardt de Montpellier), UMR 5253, Universite de Montpellier, \\ Place E. Bataillon, F-34095, Montpellier, France.
}

*Corresponding author. E-mail: mikhael.bechelany@univ-montp2.fr

* Corresponding author. E-mail: Sophie.Tingry@univ-montp2.fr

\begin{abstract}
We present the effect of thermal treatment of carbon felt by gas flow containing $1 \%$ of oxygen at high temperature on the direct electron transfer and electrocatalytic oxygen reduction currents by a bilirubin oxidase (BOD) film directly adsorbed in the presence of carbon nanotubes on to a porous carbon felt (PCF). The upgraded properties (surface area, pore volume and hydrophilicity) of the resulting porous carbon felt (PCF) in comparison to commercial carbon felt (raw CF), creates a suitable support for the entrapment of MWCNTs bearing negative charges at neutral $\mathrm{pH}$ and $\mathrm{BOD}$ enzymes, all the components being entrapped in chitosan layer reticulated with glutaraldehyde. Since functional MWCNTs are
\end{abstract}


usually used to facilitate DET, we introduce COOH@MWCNTs, bearing negative charges at neutral $\mathrm{pH}$, in the enzyme layer to evaluate their impact on the electron transfer properties with BOD. The enzyme immobilization efficiency is examined by varying the amount of the components and the immobilization procedure. Linear sweep voltammetry (LSV) and chronoamperometry measurements are used to evaluate the electrochemical behavior of the enzymatic biocathodes. Based on the experimental results, we show that the optimized bioelectrode delivers a current density of $3.70 \mathrm{~mA} \mathrm{~cm}^{-2}$ at $0.15 \mathrm{~V}$ vs $\mathrm{Ag} / \mathrm{AgCl}$ and could retain above $55 \%$ of its initial response after 4 months, proving its outstanding performance. This new bioelectrode allows for optimal DET-type bioelectrocatalytic activity toward $\mathrm{O}_{2}$ reduction and is a very promising candidate for the construction of 3-dimensional cathodes in (bio)-electrochemical devices needing high current output.

Keywords: Carbon nanotubes, porous carbon felt, electroenzymatic reduction, electrostatic interactions, direct electron transfer, storage stability.

\section{Introduction}

Performance and operational stability of enzymatic electrodes have been addressed to design electrocatalytic biomaterials for bioenergy conversion, biosensing and bioreactors. Strategies have been developed to improve the electronic wiring of the redox enzymes through optimal methods in order to effectively incorporate enzymes into appropriate electrode materials, considering their fragile three dimensional conformation $[1,2]$. The electrical connection of the enzymes to the electrode surface can be performed either by Mediated Electron Transfer (MET) in the presence of a redox mediator or by Direct Electron Transfer (DET). The advantage of the DET is the simplification in the construction of the bioelectrode, the absence of mediators that are 
often health hazards and that may affect the kinetics and thermodynamics of the electrochemical reaction. However, DET is influenced by proper enzyme orientation to perform direct wiring with the electrode surface and the efficiency of the mechanism depends on the amount of enzyme connected $[3,4]$.

Bilirubin oxidase (BOD), a blue multi-copper oxydoreductase enzyme, has been recognized as a highly efficient oxygen reduction catalyst at near neutral $\mathrm{pH}$ and at low-overpotential $[5,6]$. The enzyme BOD contains four redox active $\mathrm{Cu}$ centers. The $\mathrm{T} 1 \mathrm{Cu}-c e n t e r$ has been proposed to be the electron-receiving center from the electrode, and the dioxygen reduction was suggested to occur at the tri-nuclear $\mathrm{Cu}$ clusters of T2/T3. Reported studies showed that the oxygen reduction is highly effective with BOD immobilized onto the surface of various types of carbon nanocomposites, such as multiwalled carbon nanotubes (MWCNTs) [7-10], graphene [11, 12], and carbon nanofibers (CNFs) [13, 14]. Among these nanostructures, functional multi-walled carbon nanotubes have been mainly used to efficiently connect the redox centers of the BOD and the electrode surface, thus creating different architectures. On the molecular scale, the functional MWCNTs walls consist of $\mathrm{sp} 2$ graphene carbon atoms with hydroxyl, amine, and carboxyl groups that exhibit better interfacial bonding strength, better dispersion and better flexibility.

Different approaches involving surface functional groups positively or negatively charged or with orientation capability have shown to drastically affect enzyme orientation and interface interactions [7, 11, 15-19]. The surroundings of the T1 site of BOD being charge positively in the $\mathrm{pH}$ range [7-10], [17], the best approach to achieve bioelectrocatalytic efficiency of ORR is to develop supports with hydrophilic surfaces and negative charges. 
In this work, we design a novel biocathode by combining the surface of porous $\mathrm{CF}$ with MWCNTs-COOH bearing negative charges that are essential to improve proper orientation of the T1 site of BOD for DET-type bioelectrocatalytic activity $[5,20]$. The three-dimensional carbon felt (CF) owns properties such as low weight, high chemical resistance, high thermal stability, and easy handling [21], and was applied in various applications relevant to water treatment [22], vanadium redox flow batteries [23-25], microbial fuel cell [26], and electrochemical technologies [27, 28]. We recently showed that thermal treatment of the CF under gas flow containing $1 \%$ of oxygen during $1 \mathrm{~h}$ at $1000{ }^{\circ} \mathrm{C}$ improves the surface area $\left(63.88 \mathrm{~m}^{2} / \mathrm{g}\right.$ value $)$ and the hydrophilic properties along with the electrochemical properties [29]. The entrapment of CNTs on the surface of the porous $\mathrm{CF}$ (CNTs/PCF) combines the attractive properties of both nanoscale and micro-meter scale material. In addition, porous structures allow for the generation of current densities in the range of $\mathrm{mA} \mathrm{cm}^{-2}$ owing to their ability to immobilize a large amount of enzymes into their intra-nanospaces [16, 30-32].

There is two common ways to combine enzymes and CNTs in enzymatic electrodes: (i) Enzymes are immobilized after fixing CNTs on dense electrodes through various techniques as drop casting [33], dip coating [34], growth of aligned MWCNTs directly onto electrode surfaces [18] and (ii) Enzymes are firstly bound to CNTs and both of them are then covered on the support or compressed into pellet for direct use as bioanode/cathode [35].

We first undertake the adsorption of the BOD enzymes by adsorption on the PCF support followed by confinement in a chitosan (CS) layer. Chitosan, an $N$-deacetylated derivative of chitin, is commonly used for immobilization enzymes due to its excellent capability for film formation, nontoxicity, biocompatibility and mechanical strength through the presence of reactive amino $\left(-\mathrm{NH}_{2}\right)$ and hydroxyl function $(-\mathrm{OH})$ groups 
anchoring on chitosan chains $[36,37]$. In our study, CS is used in combination with glutaraldehyde (GA), because it can be easily crosslinked by reagents such as GA or formaldehyde to form a rigid aquagel [38]. The efficiency of the enzyme immobilization made by impregnation on the porous electrode is examined by varying the amount of chitosan and glutaraldehyde components. Since functional MWCNTs are usually used to facilitate DET, in a second step we introduce COOH@MWCNTs, bearing negative charges at neutral $\mathrm{pH}$, in the enzyme layer to evaluate their impact on the electron transfer properties with BOD. In addition, the free carboxyl groups of the CNTs can react with chitosan via crosslinking using glutaraldehyde and retain the enzyme bioactivity for a long period $[39,40]$.

Linear sweep voltammetry (LSV) and chronoamperometry measurements were used to evaluate the electrochemical behavior of the enzymatic biocathodes. We explore the interactions between the components of the biocathode on the DET-type bioelectrocatalytic activity of BOD to propose a bioelectrode which exhibits high catalytic activity and longevity for oxygen reduction. We evaluate the efficiency of the orientation of BOD on charged surfaces by evaluating the ratio between MET/DET in addition to the DET current value obtained by LSV experiments. This new electrode promises to bring useful and interesting development for (bio)-electrochemical applications.

\section{Experimental}

\section{1. Materials}

The multi-walled carbon nanotubes (Thin MWCNTs@COOH, 95 \%) were obtained from Nanocyl S. A, Belgium. The carbon felt was purchased from A Johnson Matthey 
Co., Germany. Potassium hexacyanoferrate $(\geq 99 \%)$ and potassium nitrate $(\geq 99 \%)$ were bought from Fluka, enzyme bilirubin oxidase Myrothecium verrucaria (BOD, 2.51 U/mg solid) from Amano Enzyme Inc., Japan; potassium hydroxide (KOH pellets pure) from Merck; glutaraldehyde (25 wt.\% in $\mathrm{H}_{2} \mathrm{O}$ ); D-(+)-glucose monohydrate; chitosan; 2,2'-azino-bis(3-ethylbenzthiazoline-6-sulfonic acid) (ABTS); acid sulfuric (98\%) from Sigma-Aldrich, and used without further purification. Dihydrogen phosphate monohydrate $\left(\mathrm{NaH}_{2} \mathrm{PO}_{4} \cdot \mathrm{H}_{2} \mathrm{O}\right)$ and di-sodium hydrogen phosphate $\left(\mathrm{Na}_{2} \mathrm{HPO}_{4}\right)$ salts from Merck were employed for the preparation of the buffer phosphate $\mathrm{pH} 7.0$ (PBS). The aqueous solutions were prepared using $18.2 \mathrm{M} \Omega \mathrm{cm}$ MilliQ water (Millipore).

\subsection{Preparation of biocathode from porous carbon felt and CNTs}

The commercial carbon felt with a dimension of $5.0 \mathrm{~cm} \times 1.0 \mathrm{~cm} \times 1.27 \mathrm{~cm}$ was first cleaned in an ultrasonic bath with acetone for $2 \mathrm{~h}$ to remove adsorbed contaminations, followed by thorough rinse with deionized water and dried at $60^{\circ} \mathrm{C}$ for $24 \mathrm{~h}$. This pretreated carbon felt was denoted as raw $\mathrm{CF}$. After that, these carbonaceous samples were thermal treated in a tubular furnace (Vecstar Ltd), feeding by a mixture of $\mathrm{N}_{2} / \mathrm{O}_{2}$ with $1 \%$ of oxygen during $1 \mathrm{~h}$ at $1000^{\circ} \mathrm{C}$ through keeping constantly the income gas flow at $200 \mathrm{~mL} / \mathrm{min}$. This sample was noted as Porous Carbon Felt (PCF).

In the following step, the biocathode was prepared according to three enzyme immobilization procedures (A, B and C) on the PCF (with a projected surface area of 1 $\mathrm{cm}^{2}$ and $1.27 \mathrm{~cm}$ thick):

(A) $300 \mu \mathrm{L}$ of the enzyme BOD $\left(19.5 \mathrm{mg} \mathrm{mL}^{-1}\right)$ in PBS at $\mathrm{pH} 7.0$ was casted on the PCF until complete absorption of the solution inside the porous electrode. The enzyme loading was calculated as $5.8 \mathrm{mg}$. After drying under a light air flow for approximately 
$1 \mathrm{~h}$, the modified electrode was covered by a layer of CS. The solution was prepared by dissolving $1 \mathrm{wt} . \%$ of $\mathrm{CS}$ in $1 \mathrm{~mL}$ of acetic acid solution $(1 \mathrm{vol} . \%)$ until complete dissolution to form a viscous solution, followed by the addition of $50 \mu \mathrm{L}$ of glutaraldehyde. The biocathode was labeled PCF-BOD (Figure 1 A).

(B) two successive layers were drop casted onto the PCF. The first layer consisted of 3 $\mathrm{mL}$ homogeneous suspension of CNTs $\left(1.67 \mathrm{mg} \mathrm{mL}^{-1}\right)$ dispersed in a mixture ethanol/water (1/9) with the aid of an ultrasonic probe system (SONOPULS HD 3100; $60 \%$ amplitude) for $1 \mathrm{~h}$ and mixed with the enzyme BOD $300 \mu \mathrm{L}\left(19.5 \mathrm{mg} \mathrm{mL}^{-1}\right)$ in PBS at $\mathrm{pH}$ 7.0. The PCF was incubated in the prepared mixture until complete absorption of the solution inside the porous electrode. After drying under a light air flow for approximately $1 \mathrm{~h}$, the modified electrode was covered by a layer of CS reticulated in the presence of glutaraldehyde. The biocathode was labeled MWCNTs@COOH/PCF-BOD (mixing) (Figure 1 B).

(C) three layers were successively drop-casted onto the carbon felt after complete absorption of the solutions inside the porous electrode. The first layer was $3 \mathrm{~mL}$ of the CNTs (1.67 $\mathrm{mg} \mathrm{mL}^{-1}$ ) homogenized in ethanol/water (1/9). The second layer was 300 $\mu \mathrm{L}$ of the BOD solution in PBS (19.5 $\left.\mathrm{mg} \mathrm{mL}^{-1}\right)(\mathrm{pH} 7.0)$. The electrode was dried after each deposition under a light air flow for approximately $1 \mathrm{~h}$. The final layer was made of CS (1 mg mL $\left.\mathrm{mL}^{-1}\right)$ reticulated by the addition of glutaraldehyde. The biocathode produced by this second method was noted as MWCNTs@COOH/PCF-BOD (layers) (Figure $1 \mathrm{C}$ ).

The same enzyme loading was used for the three methods A, B and C. In this study, we did not investigate the impact of the fabrication method on the loading of BOD. The different performances of biocathodes fabricated by these three methods were evaluated by measuring the generated current by linear sweep voltammetry (LSV) 
measurements and the stability by chronoamperometry measurements. The differences come from the immobilization methods that influence the electrostatic interactions and thus the orientation of the enzymes for efficient electron transfer. The resulting bioelectrodes were dried at $5{ }^{\circ} \mathrm{C}$ for $48 \mathrm{~h}$ before the test regarding the $\mathrm{O}_{2}$ reduction reaction. After the first test, the electrodes were stored in the fridge in a PBS at ( $\mathrm{pH} 7)$ until further stability tests were performed.

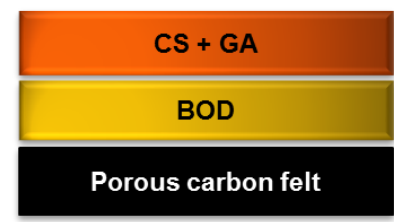

(A) PCF-BOD

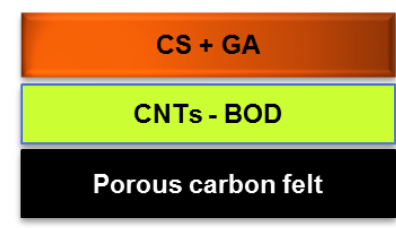

(B) MWCNTs@COOH/PCF-BOD (mixing)

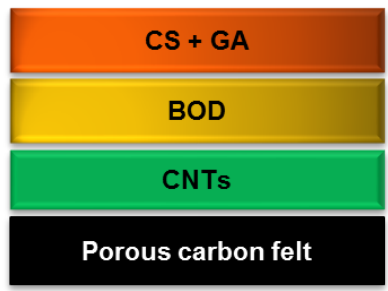

(C) MWCNTs@COOH/PCF-BOD (layers)

Figure 1. Scheme of the three different enzyme immobilization procedures (A, B, C) on the PCF electrode supports based on the components: BOD, CNTs, Chitosan (CS) and glutaraldehyde (GA).

The enzyme loading was calculated as $5.8 \mathrm{mg}$ according to the procedures of enzyme immobilization, however, when the electrodes are soaked in solution, enzyme leaching occurred. The amount of BOD non-specifically immobilized on the raw, PCF and MWCNTs@COOH/PCF biocathodes was estimated from the difference in enzyme concentration in the solution where the biocathodes were immersed before and after enzyme adsorption. The enzyme concentration was evaluated by measuring the activity of BOD by spectrophotometry from the oxidation rate of $\mathrm{ABTS}^{2-}$ in $0.1 \mathrm{M}$ phosphate buffer of pH 7.0 at ambient temperature under air bubbling. The increase in absorbance corresponded to the production rate of ABTS $^{-}$oxidation product and was followed at $420 \mathrm{~nm}$. As observed in Table 1, enzyme leaching mainly occurred for the raw CF 
bioelectrodes (34.5\%), in contrast with the PCF-BOD and MWCNTs@COOH/PCFBOD electrodes which only lost 3.6 and $1.3 \%$, respectively.

Table 1: Estimated BOD leaching and final BOD loading on the biocathodes for the raw CF, PCF and MWCNTs@COOH/PCF electrodes.

\begin{tabular}{|c|c|c|c|}
\hline & raw CF-BOD & PCF-BOD & MWCNTs@COOH/PCF-BOD \\
\hline Enzyme leaching (\%) & 34.5 & 3.6 & 1.3 \\
\hline Final enzyme loading (mg) & 3.80 & 5.60 & 5.79 \\
\hline
\end{tabular}

\subsection{Electrode characterization}

The morphology of the electrodes was characterized by scanning electron microscopy (SEM, Hitachi S-4800), home-made contact angle meter, Raman X-Ray (Raman OMARS 89 (DILOR)), and X-ray photoelectron spectroscopy (XPS) on an ESCALAB 250 (Thermo Electron) with a monochromatic A1 K $\alpha(1486.6 \mathrm{eV})$ source. The analyzed surface had a $400 \mu \mathrm{m}$ diameter. The background signal was removed using the Shirley method [41]. The surface atomic concentrations were determined from photoelectron peaks areas using the atomic sensitivity factors reported by Scofield [42]. Binding energies (BE) of all core levels were referred to the $\mathrm{C}=\mathrm{C}$ of $\mathrm{C} 1 \mathrm{~s}$ carbon at $284.4 \mathrm{eV}$.

Electrochemical measurements were carried out using an Ametek-Versa Stat 3 potentiostat on a conventional three-electrode assembly composed of a stainless steel counter electrode, an $\mathrm{Ag} / \mathrm{AgCl}$ (saturated $\mathrm{KCl}$ ) reference electrode, and the modified PCFs as working electrode. Oxygen reduction was performed by linear sweep voltammetry (LSV at a scan rate of $3 \mathrm{mV} \mathrm{s}^{-1}$ ) and chronoamperometry measurements (at a fixed potential of $0.3 \mathrm{~V}$ vs. $\mathrm{Ag} / \mathrm{AgCl}$ ) in $\mathrm{O}_{2}$-saturated $\mathrm{PBS}(\mathrm{pH} 7.0,0.1 \mathrm{M}$ ) after stabilization of the open circuit potential of BOD-modified biocathode. The current 
density was normalized by the projected surface area of the electrodes, i.e. the geometrical area of the base of a parallelepiped rectangle. The stability of the biocathodes was monitored during 4 months.

\section{Results and discussion}

\subsection{Material characteristic}

The structural morphology of the PCF material was first characterized before using as support in the construction of enzymatic electrode. SEM experiments highlight the different steps in the fabrication of the electrode support (Figure 2). The raw $\mathrm{CF}$ (Figure 2 a) is characterized by a smooth surface (with low surface area $0.09 \mathrm{~m}^{2} / \mathrm{g}$ [29]), whereas the PCF (Figure $2 \mathrm{~b}$ ) is rough and porous, as the result of thermal treatment by gas flow containing $1 \%$ of oxygen at high temperature. Due to its outstanding properties (surface area of $63.9 \mathrm{~m}^{2} / \mathrm{g}$ and pore volume of $0.071 \mathrm{~cm}^{3} / \mathrm{g}$ calculated by BET which is 700 times higher than the raw $\mathrm{CF}$ [29]), PCF becomes a suitable support for the homogeneous coating of MWCNTs@COOH in its porous structure (Figure $2 \mathrm{c}$ ).
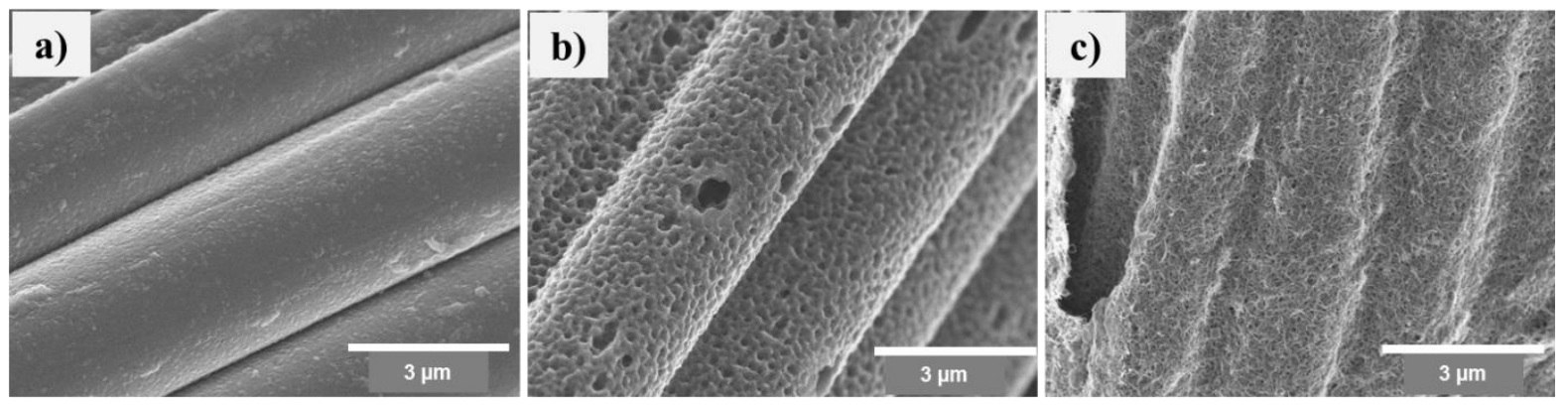

Figure 2. Surface morphology of (a) raw CF, (b) PCF and (c) MWCNTs@COOH-PCF at the same magnification 
The presence of the CNTs on the PCF support was pointed out by the Raman spectra in Figure 3. The graphitic structure of the raw CF, PCF and CNTs-PCF is depicted by the representative peaks at $1322 \mathrm{~cm}^{-1}, 1583 \mathrm{~cm}^{-1}$ corresponding to the $\mathrm{D}$ band and $\mathrm{G}$ band, respectively and their overtones at $2640 \mathrm{~cm}^{-1}$ and $2903 \mathrm{~cm}^{-1}$. The $\mathrm{G}$ band is characteristic for the zone center vibration of carbon atoms against each other's in the layer planes and $\mathrm{G}$ band shows the vibration mode of $\mathrm{sp}^{2}$-bonded carbon atoms in a $2 \mathrm{D}$ hexagonal lattice. The intensity ratio between the D band and G band of CNTs-PCF (1.584) increases in comparison to 1.250 and 1.414 for PCF and raw $\mathrm{CF}$, respectively, which proves the successful modification of MWCNTs-COOH on PCF support. We note here that this high value of $\left(\mathrm{I}_{\mathrm{D}} / \mathrm{I}_{\mathrm{G}}\right)$ indicates the presence of high degree of disorder in the multilayer configuration of multiwall carbon nanotubes [43, 44].

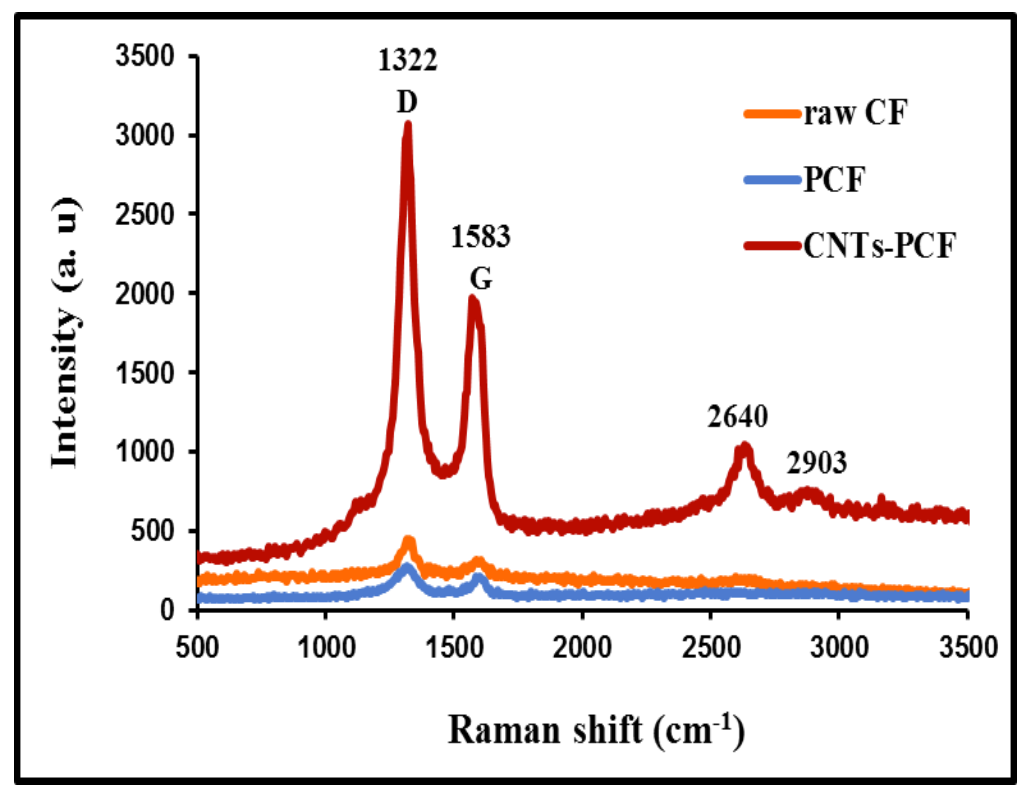

Figure 3. Comparison of Raman spectra of raw CF, PCF and CNTs-PCF

Further investigations on the surface composition of the electrodes were performed by XPS analysis, as shown in Figure 4, and the elemental compositions of the presented materials were listed in Table 2. The XPS spectra clearly show the presence of carbon 
with the appearance of $\mathrm{C}=\mathrm{C}$ bonds at $284.4 \mathrm{eV}, \mathrm{C}-\mathrm{C}$ at $285 \mathrm{eV}$ and of carbon-oxygen bonds like $\mathrm{C}-\mathrm{O}$ at $286.2 \mathrm{eV}, \mathrm{C}=\mathrm{O}$ at $288 \mathrm{eV}$, and $\mathrm{COOH}$ at $289 \mathrm{eV}$. The $\mathrm{O} / \mathrm{C}$ ratio increases from 0.03 for raw $\mathrm{CF}$ to 0.09 for $\mathrm{CNTs}-\mathrm{PCF}$, due to the carboxylate groups $(\mathrm{COOH})$ anchored in MWCNTs framework. The significant rise of this ratio for PCF, 0.16, comes from the presence of functional oxygen groups induced by thermal treatment at high temperature under a nitrogen gas flow mixed with $1 \%$ of oxygen. The appearance of oxygen groups contributes to the hydrophilic improvement of PCF and CNTs-PCF for growth of immobilized enzyme amount.
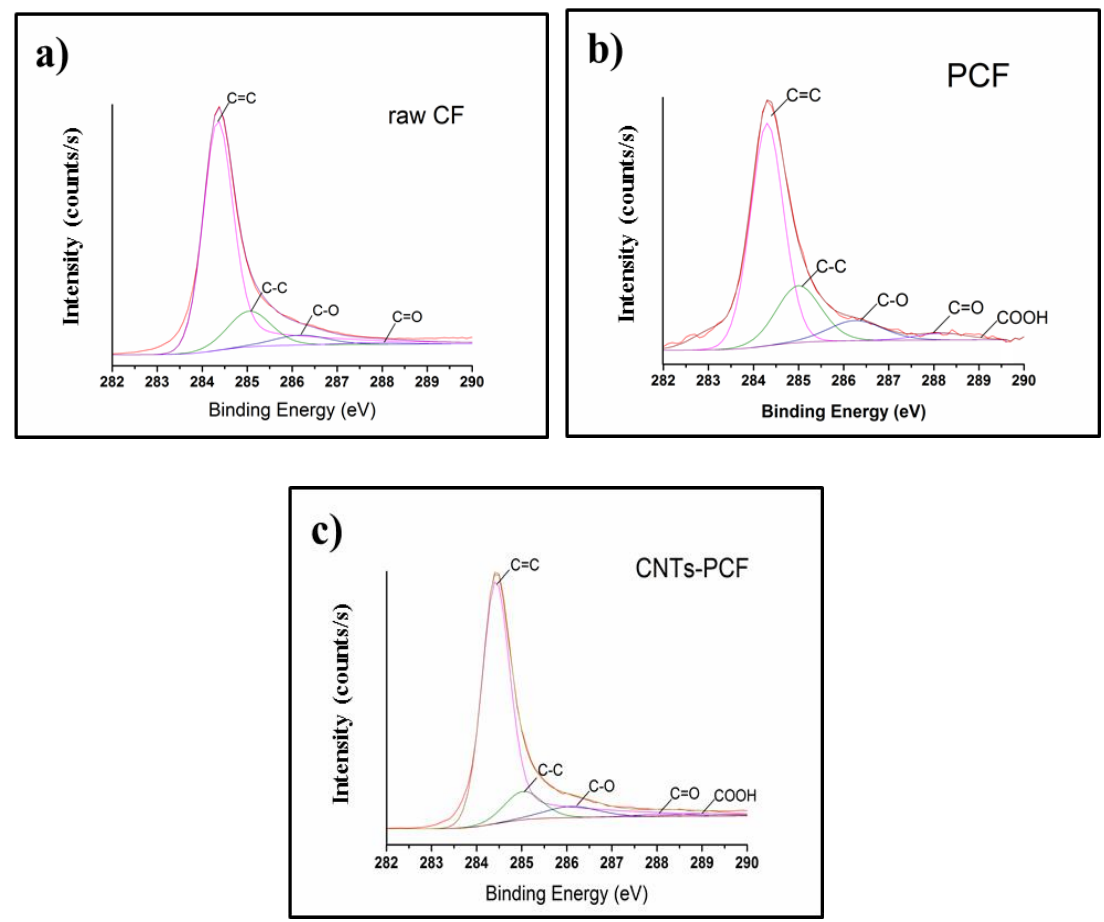

Figure 4. C1s XPS spectra of (a) raw CF, (b) PCF and (c) CNTs-PCF

Table 2. The compositions of carbon and oxygen in raw CF, PCF and CNTs-PCF

\begin{tabular}{|c|c|c|}
\hline Name & XPS peak & At. \% \\
\hline \multirow{2}{*}{ raw CF } & $\mathrm{C}_{1 \mathrm{~s}}$ & 97.0 \\
\cline { 2 - 3 } & $\mathrm{O}_{1 \mathrm{~s}}$ & 3.0 \\
\hline
\end{tabular}




\begin{tabular}{|c|c|c|}
\hline Name & XPS peak & At. \% \\
\hline \multirow{2}{*}{ PCF } & $\mathrm{C}_{1 \mathrm{~s}}$ & 86.4 \\
\cline { 2 - 3 } & $\mathrm{O}_{1 \mathrm{~s}}$ & 13.6 \\
\hline \multirow{2}{*}{ CNTs-PCF } & $\mathrm{C}_{1 \mathrm{~s}}$ & 92.1 \\
\cline { 2 - 3 } & $\mathrm{O}_{1 \mathrm{~s}}$ & 7.9 \\
\hline
\end{tabular}

\subsection{Optimization of the enzymatic biocathode for efficient $\mathrm{O}_{2}$ electroreduction}

The PCF support was herein employed as support to construct a BOD/chitosan layerbased biocathode applied to the DET reaction of oxygen electro-reduction. First, for determining optimization of the enzyme layer, we inspected the influence of the two components glutaraldehyde (GA) and chitosan (CS). Second, carboxylated-MWCNTs were incorporated into the layer to improve the connection between the redox centers of the enzyme and the electrode surface. LSV and chronoamperometry measurements were performed to evaluate the electrochemical behavior of the enzymatic biocathodes toward the $\mathrm{O}_{2}$ electroreduction.

\subsubsection{Influence of Glutaraldehyde (GA) amount}

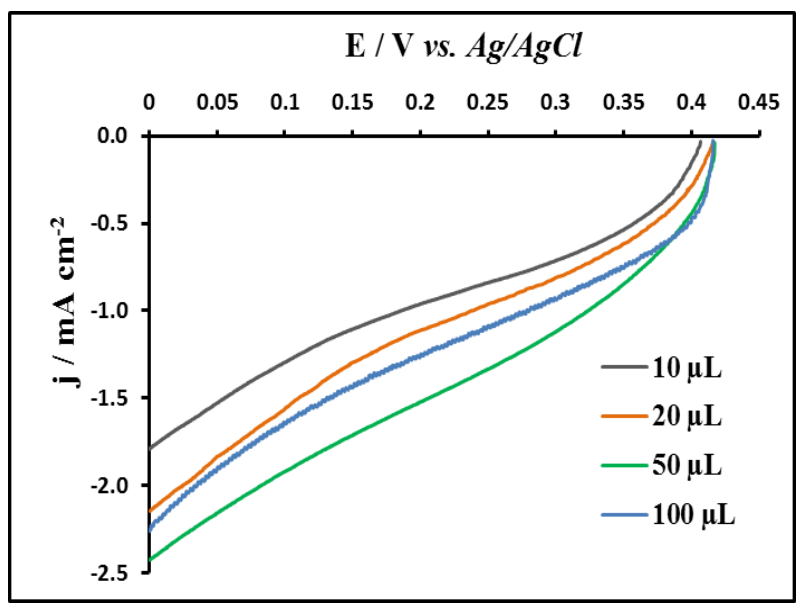


Figure 5. LSV curves of $\mathrm{O}_{2}$ electroreduction on the PCF biocathode immobilized with the enzyme BOD entrapped in a chitosan layer with different amounts of glutaraldehyde. Scan rate of $3 \mathrm{mV} \mathrm{s}^{-1}, \mathrm{O}_{2}$-saturated $\mathrm{PBS} 0.1 \mathrm{M}, \mathrm{pH} 7.0$ at $30{ }^{\circ} \mathrm{C}$.

The PCF support was modified with enzymes entrapped in CS matrix in the presence of GA. The purpose of employing glutaraldehyde is to reticulate the chitosan film in order to create a denser and more stable structure, able to keep the enzymes active. GA has two aldehyde functionalities and is able to form covalent bonds both between $\mathrm{NH}_{2}$ groups from different $\mathrm{CS}$ chains and between $\mathrm{NH}_{2}$ groups of enzyme and CS [45]. To evaluate the effect of glutaraldehyde towards the electrochemical performance of the electrode, various amounts of GA $(10,20,50,100 \mu \mathrm{L}$ at concentration of $25 \%)$ were dissolved in $1 \mathrm{wt} . \%$ of $\mathrm{CS}$ in $1 \mathrm{~mL}$ of acetic acid solution. The resulting LSV curves, obtained in $\mathrm{O}_{2}$-saturated PBS at $\mathrm{pH} 7.0$ (Figure 5), show that the average open circuit potential is $0.42 \mathrm{~V}$ vs $\mathrm{Ag} / \mathrm{AgCl}$ (in good agreement with reported values for BOD Myrothecium verrucaria [46]), and the increase of GA amount in the range of $10 \mu \mathrm{L}$ $50 \mu \mathrm{L}$ affects the catalytic activity of the electrodes. At $0.15 \mathrm{~V}$ vs $\mathrm{Ag} / \mathrm{AgCl}$, the current density increases from $1104 \mu \mathrm{A} \mathrm{cm} \mathrm{cm}^{-2}$ to $1708 \mu \mathrm{A} \mathrm{cm} \mathrm{cm}^{-2}$ for $10 \mu \mathrm{L}$ and $50 \mu \mathrm{L}$, respectively. However, an higher amount of GA causes excessive crosslinking and that might impede the access of active BOD [47]. Therefore, GA is effective in enhancing catalytic activity of the enzymatic layer, contrary to layer-by-layer configuration based on the polymer polyaniline where the usage of GA only influenced the leaching-out of enzymes and thus the electrode stability [46]. In our study, $50 \mu \mathrm{L}$ of GA solution was considered as the optimal amount of the crosslinking reagent for the preparation of the CS layer.

Besides, the shape of the curves indicates that at high potentials, the catalytic wave has a quasi-sigmoidal shape, whereas at lower potentials the current gradually increases 
without reaching a real plateau, suggesting that the bioelectrocatalytic process is ratelimited by a dispersion of interfacial DET rates, as it has been already reported $[30,48$, 49]. During adsorption process, the enzyme molecules may adopt a dispersion of possible orientations while maintaining electron exchange with the electrode surface.

\subsubsection{Influence of Chitosan (CS) amount}

The usage of CS aims to improve the enzyme absorption and the stability of biocathodes, whereas in its absence biocathodes can present lower stability with a loss of enzyme activity up to 5-8 times higher compared to chitosan film-coated electrode [50]. Based on our above results, different concentrations of chitosan $(0.5,1,2,4$ wt.\%) were evaluated to find out the best polymer layer. The catalytic activity and the stability of the biocathodes were gained by measuring on LSV curves the delivered current density at the fixed potential of $0.15 \mathrm{~V}$ ( $v \mathrm{~s} \mathrm{Ag} / \mathrm{AgCl}$ ) under periodic measurements for one month. As shown in Figure 6, for the lowest CS concentration of $0.5 \%$, the biocathode rapidly loses its activity the first 10 days. After 1 month, the electroactivity of the biocathode was only $28.5 \%$ of its initial activity. For higher CS concentrations, more than $60 \%$ of the initial current density is retained after one month. This confirms that the longevity of the biocathode is prolonged by the CS that promotes the adhesion capability of active immobilized enzymes [51]. Nevertheless, it should be noted that a too thick layer of CS on the electrode surface induces a negative function which hinders the DET between redox enzymes and electrode, because CS is nearly nonconductive and hampers the transition of electron [52]. Indeed, the current density value is higher with the presence of CS $1 \mathrm{wt} . \%$, indicating that this value is the best to prepare the biocathodes. 


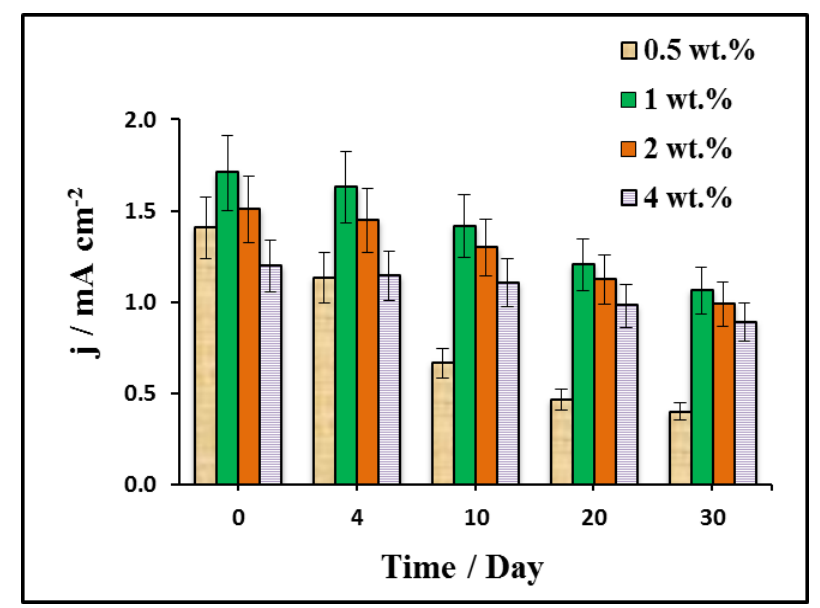

Figure 6. Long-term stability study of the BOD bioelectrodes evaluated from the maximum current densities at $0.15 \mathrm{~V} v s \mathrm{Ag} / \mathrm{AgCl}$ extracted from LSV curves toward $\mathrm{O}_{2}$ electroreduction in $\mathrm{O}_{2}$ saturated PBS ( $\left.\mathrm{pH} 7.0\right)$, with different concentrations of chitosan $(0.5,1,2,4$ wt.\%). Bioelectrodes stored in PBS solution at $5{ }^{\circ} \mathrm{C}$ between measurements. (RSD: $12 \%(\mathrm{n}=3)$ ).

\subsubsection{Influence of the procedure for enzyme immobilization}

Figure 1 shows the schematic illustrations of the three procedures to construct the enzyme layer. The catalytic layer was modified by adding MWCNTs@COOH following two ways: (i) the enzymes and the MWCNTs were mixed previous their immobilization (procedure B); and (ii) a first layer of MWCNTs was casted onto the support followed by a second layer of BOD (procedure C).

To deduce the optimized procedure that promotes enzyme orientation for efficient DET mechanism, LSV and chronoamperometry measurements were performed for the biocathodes: raw CF-BOD, PCF-BOD, MWCNTs@COOH/PCF-BOD (mixing) and MWCNTs@COOH/PCF-BOD (mixing) and MWCNTs@COOH/PCF-BOD (layers) (Figure 7). To claim that direct current production is catalyzed by bilirubin oxidase, additional LSV experiments were performed on raw CF, PCF, MWCNTs@COOH/PCF electrodes without immobilizing BOD enzyme. The resulting 
LSV curves are presented in Figure S1. It is obvious from the open circuit potential and the current densities that the $\mathrm{O}_{2}$ reduction is catalyzed by the enzyme. Regarding Figure 7a, two noticeable effects are observed: first, PCF electrode exposes a substantial advance as its cathodic current density is 8 times higher than bare CF that delivers approximately $300 \mu \mathrm{A} \mathrm{cm}$. The improvement of the surface area and the hydrophilicity by thermal treatment of the PCF support allows low leaching of the enzymes from the electrode (3.6\%, see Table 1) compared to the raw CF support (34.5\%), thus demonstrating that the porosity promotes enzyme loading [29].

Second, the response of the current density curve for the PCF-BOD and MWCNTs@COOH/PCF-BOD biocathodes is almost linear over the whole potential range. This result indicates that the two carbon materials present regions with different charged surfaces that may induce superposition of different electrochemical rate constants [48]. Besides, in the presence of the MWCNTs@COOH in the enzyme layer of the biocathode, the open circuit potential shits nearly $50 \mathrm{mV}$ more positive $(0.45 \mathrm{~V}$ vs $\mathrm{Ag} / \mathrm{AgCl}$ ) and the delivered current is higher. To recognize the role of the PCF material and the MWCNTs, the active surface area was evaluated from cyclic voltammetry curves plotted in phosphate buffer $(\mathrm{pH}$ 7), and presented in Figure S2. The presence of the micropores in PCF material results in a huge increase in the envelope current in comparison to the raw $\mathrm{CF}$ that is even more pronounced with the addition of the MWCNTs, meaning that the nanostructures induce further improvement in active surface area. Besides, the final enzyme loading being similar for both kinds of biocathodes (see Table 1), one can assume that the presence of CNTs are essential to improve proper orientation of the $\mathrm{T} 1$ site of BOD for efficient DET-type bioelectrocatalytic activity. 
It was also observed that the mixing of the CNTs with the enzymes in the biocathode MWCNTs@COOH/PCF-BOD (designated as “mixing”) allows better direct electrical connection compared to the layered structure of the biocathode MWCNTs@COOH/PCF-BOD (designated as "layers"). In fact, we can assume that mixing the enzymes and the CNTs previous to their immobilization (procedure B) allows high contact between MWCNTs and BOD which induced better efficient vicinity in comparison to the layered methods (procedure C). The high surface area, the hydrophilicity, and porous structure of the PCF used in this work provides for high access to the active enzymes and CNTs in the whole framework that influence the electrostatic interactions and thus the orientation of the enzymes for efficient electron transfer.

The efficiency of the DET was characterized by measuring the ratio of the current density in the absence and in presence of the redox mediator ABTS $(0.5 \mathrm{mM})$ introduced in the solution when the biocathodes were polarized with a constant potential $(0.15 \mathrm{~V}$ vs. $\mathrm{Ag} / \mathrm{AgCl})[7,19,53]$. ABTS is a small and soluble molecule that promotes electron relays to approach all the active enzymes in the layer contributing to mediated electron transfer (MET) [14]. The relative ratio of the generated current density before and after the addition of ABTS thus indicates the proportion of BOD for which the specific orientation does not allow direct electrical connection. The experiment was conducted at $0.15 \mathrm{~V}$ vs. $\mathrm{Ag} / \mathrm{AgCl}$ where the electron transfer rate is fast. As shown in Figure $7 b$, the generated current is very low on the raw $\mathrm{CF}$ biocathode indicating a poor DET for dioxygen reduction, and increases rapidly to 1.5 $\mathrm{mA} \mathrm{cm} \mathrm{cm}^{-2}$ upon addition of ABTS. However, for the PCF-BOD, the proportion of the current density before and after addition of ABTS in the solution was around $0.5 \mathrm{~mA}$ $\mathrm{cm}^{-2}$, indicating that almost half of the enzymes amount is properly oriented to undergo 
DET. The enhanced current density, before the addition of ABTS, confirms improvements of the surface area and hydrophilicity of the electrode surface by thermal treatment that promote better access to the enzymes and oxygen diffusion to the electrode surface. Finally, a strong amelioration of the electroactivity of the biocathode MWCNTs@COOH/PCF-BOD (mixing) is noticed in the presence of the MWCNTs@COOH. The generated current density is the highest and is not affected in the presence of ABTS, suggesting that the presence of the MWCNTs with negatively charged surface provides an extra enhancement of the immobilized enzyme DET reaction rate. This result confirms the importance of both the charge of the electrode surface and the surroundings of the $\mathrm{T} 1$ site to ensure proper and efficient electrical connection of the adsorbed enzymes [19]. Although comparison with literature is not straightforward (due to differences in enzyme activities, concentrations, electrode materials, etc.), PCF bioelectrodes presented competitive efficiency with other reported works focusing on nanostructured electrodes for bioelectrocatalysis of dioxygen reduction. For example, according to Flexer et al., the stability of the catalytic current on the porous biocathode electrode (carbonaceous micro/macrocellular-BOD) foams during several days have shown very promising results, with current losses below $20 \%$ per day, after the first day [30]. This electrode could generate a catalytic current density of $2.1 \mathrm{~mA} \mathrm{~cm}^{-2}$ at $0 \mathrm{~V}$ vs. $\mathrm{Ag} / \mathrm{AgCl}$. Comparing to this result, our work presented better result when after 10 days, the loss was $20 \%$ and the current density at $0 \mathrm{~V}$ vs. $\mathrm{Ag} / \mathrm{AgCl}$ for MWCNTs@COOH/PCF-BOD (mixing) biocathode was $3.7 \mathrm{~mA}$ $\mathrm{cm}^{-2}$ 

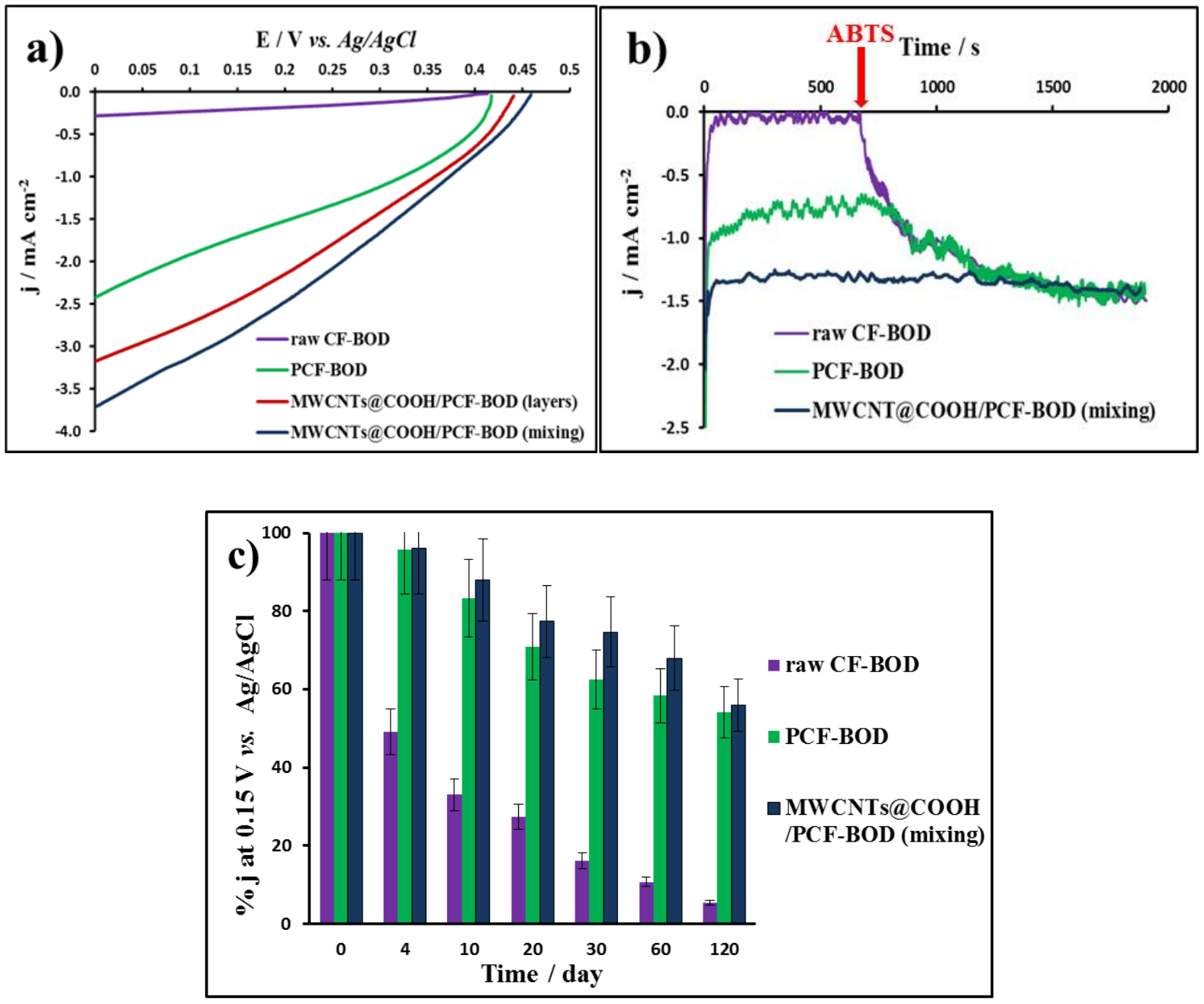

Figure 7. LSV curves of $\mathrm{O}_{2}$ electroreduction at scan rate of $3 \mathrm{mV} \mathrm{s}^{-1}$, in $\mathrm{O}_{2}$-saturated PBS 0.1 $\mathrm{M}, \mathrm{pH} 7.0$; b) Chronoamperometry measurements at $0.15 \mathrm{~V}$ vs. $\mathrm{Ag} / \mathrm{AgCl}$ before and after the addition of ABTS $0.5 \mathrm{mM}$ in the solution for the different biocathodes; and (c) Storage stability of raw CF-BOD, PCF-BOD, MWCNTs@COOH/PCF-BOD (mixing) biocathodes. (RSD: $12 \%(\mathrm{n}=3))$.

With the determination of the best MWCNTs@COOH/PCF-BOD (mixing) layer configuration, the amount of CNTs was varied in the enzyme layer and the current density was measured at $0.15 \mathrm{~V}$ vs $\mathrm{Ag} / \mathrm{AgCl}$ from $\mathrm{LSV}$ experiments (Figure 8). The benefit coming from the CNTs usage is observed in the range from $1 \mathrm{mg}$ to $5 \mathrm{mg}$ for which the steady state value is reached. Hence, despite the excess of $10 \mathrm{mg}$ of CNTs, 
the delivered current density still keeps almost unchanged suggesting that the increase of the electroactive surface area promoted by the MWCNTs is not fully saturated by the enzymes. To claim this hypothesis, additional cyclic voltammetry curves were plotted in phosphate buffer of pH 7 and presented in Figure S3. As observed, the active surface area increases in the presence of higher MWCNT loading.

After 20 days, the electrodes exhibit between 70 and $78 \%$ of their initial activity that supports the benefit of the CS+GA layer to prolong the longevity and the adhesion capability of active immobilized enzymes [51].

Finally, in view of practical applications, we investigated the stability of the biocathode adopting the configuration MWCNTs@COOH/PCF-BOD (mixing) (with 5 mg of CNTs) by measuring the electrochemical activity for the Oxygen Reduction Reaction by LSV over a longer period of 4 months (Figure 7c). The stability of the biocathodes raw CF-BOD and PCF-BOD bioelectrodes was also studied for comparison. The electrodes were stored at $5^{\circ} \mathrm{C}$ between each test. The electrodes MWCNTs@COOH/PCF-BOD (mixing) and PCF-BOD still kept $55 \%$ and 53\% of their original activity owing to the upgraded properties of PCF (surface area and pore volume), creating a suitable support for favorable DET process and enzyme interactions with its porous structure and for the $\mathrm{O}_{2}$ diffusion, resulting to biocathodes with outstanding performance for biofuel cell applications. Work is now in progress in in order to design a new cell and modify our equipment in order to be able to determine the practical stability of the cell. 


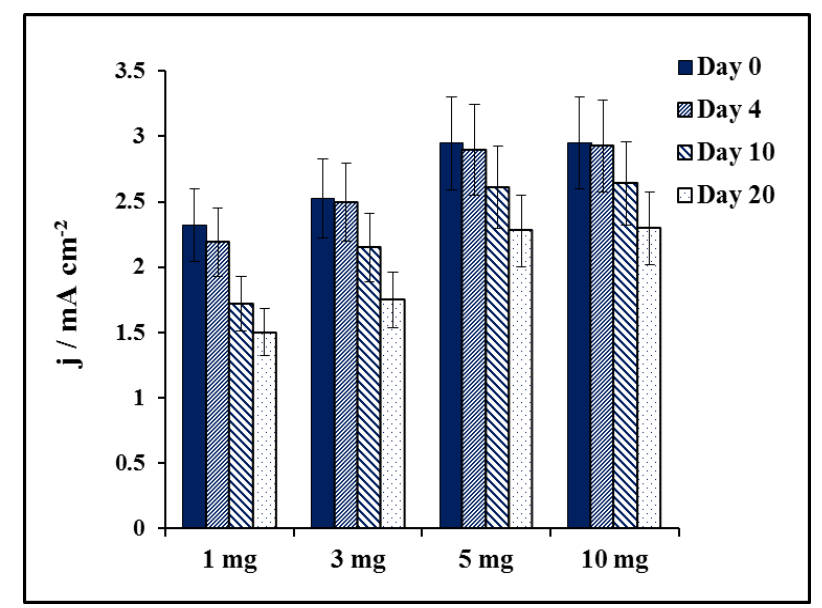

Figure 8. Delivered current density $\left(\mathrm{mA} \mathrm{cm}^{-2}\right)$ measured at $0.15 \mathrm{~V} v s . \mathrm{Ag} / \mathrm{AgCl}$ as a function of time of the MWCNTs@COOH/PCF-BOD (mixing) biocathode for different CNTs amounts. (RSD: $12 \%(n=3))$.

\section{Conclusions}

We propose an efficient interface for enzymatic electrocatalysis of $\mathrm{O}_{2}$ reduction by the enzyme BOD that combines a porous carbon felt (PCF) with hydrophilic surface properties generated by thermal treatment and MWCNTs@COOH owing negative charges. The improvement of the surface area, hydrophilicity, and porous structure of the PCF, without the use of specific reagents, provides for high access to active enzymes and CNTs in the whole framework of the PCF to prolong the electrochemical storage stability in the presence of chitosan and glutaraldehyde.

The combination of many factors (hydrophilic property of PCF, GA crosslinking, adhesion capability of CS, promoter of carboxylated MWCNTs) at the same time upgrades considerably the electrochemical performance and the lifetime of the new biocathode. We show that mixing the enzymes and the CNTs previous their immobilization is more favorable for better orientation of the $\mathrm{T} 1$ vicinity of the BOD by the charged surface of the CNTs. Based on the ratio of MET/DET with a value 
almost zero, deduced from chronoamperometry measurements, we show that the resulting material allows for optimal DET-type bioelectrocatalytic activity toward $\mathrm{O}_{2}$ reduction. The construction of this 3-dimensional electrode promises to bring useful and interesting development for (bio)-electrochemical needing high current output such as biofuel cells.

\section{Acknowledgements}

We gratefully acknowledge financial support from Vietnamese government (VIEDVietnam International Education Development - Project 911).

\section{References}

1 [1] E. Hao Yu and K. Scott, "Enzymatic Biofuel Cells-Fabrication of Enzyme Electrodes," Energies, vol. 3, pp. 23-42, 2010.

2 [2] A. de Poulpiquet, A. Ciaccafava, and E. Lojou, "New trends in enzyme immobilization at nanostructured interfaces for efficient electrocatalysis in biofuel cells," Electrochimica Acta, vol. 126, pp. 104-114, 2014.

3 [3] S. Shleev, M. Pita, A. I. Yaropolov, T. Ruzgas, and L. Gorton, "Direct Heterogeneous Electron Transfer Reactions ofTrametes hirsuta Laccase at Bare and Thiol-Modified Gold Electrodes," Electroanalysis, vol. 18, pp. 1901-1908, 2006.

4 [4] V. Krikstolaityte, A. Barrantes, A. Ramanavicius, T. Arnebrant, S. Shleev, and T. Ruzgas, "Bioelectrocatalytic reduction of oxygen at gold nanoparticles modified with laccase," Bioelectrochemistry, vol. 95, pp. 1-6, Feb 2014.

5 [5] L. Dos Santos, V. Climent, C. F. Blanford, and F. A. Armstrong, "Mechanistic studies of the 'blue' Cu enzyme, bilirubin oxidase, as a highly efficient electrocatalyst for the oxygen reduction reaction," Physical chemistry chemical physics : PCCP, vol. 12, pp. 13962-74, Nov 142010.

$6 \quad[6] \quad$ S. Brocato, C. Lau, and P. Atanassov, "Mechanistic study of direct electron transfer in bilirubin oxidase," Electrochimica Acta, vol. 61, pp. 44-49, 2012.

$7 \quad$ [7] R. J. Lopez, S. Babanova, Y. Ulyanova, S. Singhal, and P. Atanassov, "Improved Interfacial Electron Transfer in Modified Bilirubin Oxidase Biocathodes," ChemElectroChem, vol. 1, pp. 241-248, 2014.

8 [8] R. D. Milton, F. Giroud, A. E. Thumser, S. D. Minteer, and R. C. Slade, "Bilirubin oxidase bioelectrocatalytic cathodes: the impact of hydrogen peroxide," Chemical communications, vol. 50, pp. 94-6, Jan 42014.

9 [9] S. Krishnan and F. A. Armstrong, "Order-of-magnitude enhancement of an enzymatic hydrogen-air fuel cell based on pyrenyl carbon nanostructures," Chemical Science, vol. 3, p. 1015, 2012.

10 [10] J. Lim, N. Cirigliano, J. Wang, and B. Dunn, "Direct electron transfer in nanostructured sol-gel electrodes containing bilirubin oxidase," Physical chemistry chemical physics : PCCP, vol. 9, pp. 1809-14, Apr 212007.

11 [11] A. Navaee, A. Salimi, and F. Jafari, "Electrochemical pretreatment of amino-carbon nanotubes on graphene support as a novel platform for bilirubin oxidase with improved bioelectrocatalytic activity towards oxygen reduction," Chemistry, vol. 21, pp. 4949-53, Mar 232015. 

graphene and their applications in biosensing and biofuel cells," Biosensors \& bioelectronics, vol. 89, pp. 8595, Mar 152017.

[13] A.-F. Che, V. Germain, M. Cretin, D. Cornu, C. Innocent, and S. Tingry, "Fabrication of free-standing electrospun carbon nanofibers as efficient electrode materials for bioelectrocatalysis," New Journal of Chemistry, vol. 35, p. 2848, 2011.

[14] A. Both Engel, Y. Holade, S. Tingry, A. Cherifi, D. Cornu, K. Servat, T. W. Napporn, and K. B. Kokoh, "Electrospun Carbon Fibers: Promising Electrode Material for Abiotic and Enzymatic Catalysis," The Journal of Physical Chemistry C, vol. 119, pp. 16724-16733, 2015.

[15] H.-q. Xia, Y. Kitazumi, O. Shirai, and K. Kano, "Enhanced direct electron transfer-type bioelectrocatalysis of bilirubin oxidase on negatively charged aromatic compound-modified carbon electrode," Journal of Electroanalytical Chemistry, vol. 763, pp. 104-109, 2016.

[16] Y. Ogawa, S. Yoshino, T. Miyake, and M. Nishizawa, "Surfactant-assisted direct electron transfer between multi-copper oxidases and carbon nanotube-based porous electrodes," Physical chemistry chemical physics : PCCP, vol. 16, pp. 13059-62, Jul 142014. [17] J. A. Cracknell, T. P. McNamara, E. D. Lowe, and C. F. Blanford, "Bilirubin oxidase from Myrothecium verrucaria: X-ray determination of the complete crystal structure and a rational surface modification for enhanced electrocatalytic O2reduction " Dalton Transactions, vol. 40, pp. 6668-6675 2011.

[18] K. Żelechowska, B. Trawiński, S. Dramińska, D. Majdecka, R. Bilewicz, and B. Kusz, "Oxygen biosensor based on carbon nanotubes directly grown on graphitic substrate," Sensors and Actuators B: Chemical, vol. 240, pp. 1308-1313, 2017.

[19] I. Mazurenko, K. Monsalve, J. Rouhana, P. Parent, C. Laffon, A. L. Goff, S. Szunerits, R. Boukherroub, M. T. Giudici-Orticoni, N. Mano, and E. Lojou, "How the Intricate Interactions between Carbon Nanotubes and Two Bilirubin Oxidases Control Direct and Mediated O2 Reduction," ACS applied materials \& interfaces, vol. 8, pp. 23074-85, Sep 72016.

[20] I. W. Schubart, G. Göbel, and F. Lisdat, "A pyrroloquinolinequinone-dependent glucose dehydrogenase (PQQ-GDH)-electrode with direct electron transfer based on polyaniline modified carbon nanotubes for biofuel cell application," Electrochimica Acta, vol. 82, pp. 224-232, 2012. "Characterization of a carbon felt electrode: structural and physical properties," Journal of Materials Chemistry, vol. 9, pp. 419-426, 1999.

[22] S. Hammami, N. Oturan, N. Bellakhal, M. Dachraoui, and M. A. Oturan, "Oxidative degradation of direct orange 61 by electro-Fenton process using a carbon felt electrode: Application of the experimental design methodology," Journal of Electroanalytical Chemistry, vol. 610, pp. 75-84, 2007.

[23] J. W. Lim and D. G. Lee, "Carbon fiber/polyethylene bipolar plate-carbon felt electrode assembly for vanadium redox flow batteries (VRFB)," Composite Structures, vol. 134, pp. 483-492, 2015.

[24] K. Oh, S. Won, and H. Ju, "Numerical study of the effects of carbon felt electrode compression in all-vanadium redox flow batteries," Electrochimica Acta, vol. 181, pp. 13-23, 2015.

[25] T. Liu, X. Li, H. Nie, C. Xu, and H. Zhang, "Investigation on the effect of catalyst on the electrochemical performance of carbon felt and graphite felt for vanadium flow batteries," Journal of Power Sources, vol. 286, pp. 73-81, 2015.

[26] H.-F. Cui, L. Du, P.-B. Guo, B. Zhu, and J. H. T. Luong, "Controlled modification of carbon nanotubes and polyaniline on macroporous graphite felt for high-performance microbial fuel cell anode," Journal of Power Sources, vol. 283, pp. 46-53, 2015.

[27] S. Cotillas, J. Llanos, M. A. Rodrigo, and P. Cañizares, "Use of carbon felt cathodes for the electrochemical reclamation of urban treated wastewaters," Applied Catalysis B: Environmental, vol. 162, pp. 252-259, 2015.

[28] L. Wang, S. Tricard, L. Cao, Y. Liang, J. Zhao, J. Fang, and W. Shen, "Prussian blue/1-butyl-3methylimidazolium tetrafluoroborate - Graphite felt electrodes for efficient electrocatalytic determination of nitrite," Sensors and Actuators B: Chemical, vol. 214, pp. 70-75, 2015. Cathode to Eliminate Paracetamol in Aqueous Medium Using Electro-Fenton System," Electrochimica Acta, vol. 188, pp. 378-384, 2016.

[30] V. Flexer, N. Brun, O. Courjean, R. Backov, and N. Mano, "Porous mediator-free enzyme carbonaceous electrodes obtained through Integrative Chemistry for biofuel cells," Energy Environ. Sci., vol. 4, pp. 2097-2106, 2011.

[31] S. D. Minteer, P. Atanassov, H. R. Luckarift, and G. R. Johnson, "New materials for biological fuel cells," Materials Today, vol. 15, pp. 166-173, 2012. 

bioelectronics, vol. 40, pp. 45-9, Feb 152013.

[33] Y. Zhao, L. Fan, Y. Zhang, Q. Que, and B. Hong, "Three-dimensional PtxNi1-x nanoclusters supported on multiwalled carbon nanotubes in enzyme-free glucose biofuel cells," Journal of Power Sources, vol. 296, pp. 30-39, 2015.

[34] D. Kashyap, C. Kim, S. Y. Kim, Y. H. Kim, G. M. Kim, P. K. Dwivedi, A. Sharma, and S. Goel, "Multi walled carbon nanotube and polyaniline coated pencil graphite based bio-cathode for enzymatic biofuel cell," International Journal of Hydrogen Energy, vol. 40, pp. 9515-9522, 2015.

[35] B. Reuillard, C. Abreu, N. Lalaoui, A. Le Goff, M. Holzinger, O. Ondel, F. Buret, and S. Cosnier, "Oneyear stability for a glucose/oxygen biofuel cell combined with $\mathrm{pH}$ reactivation of the laccase/carbon nanotube biocathode," Bioelectrochemistry, vol. 106, pp. 73-6, Dec 2015.

[36] S. Li, X. Zhu, W. Zhang, G. Xie, and W. Feng, "Hydrogen peroxide biosensor based on gold nanoparticles/thionine/gold nanoparticles/multi-walled carbon nanotubes-chitosans composite filmmodified electrode," Applied Surface Science, vol. 258, pp. 2802-2807, 2012.

[37] Y. Hu, Z. Zhang, J. Li, H. Zhang, L. Luo, and S. Yao, "Electrochemical imprinted sensor for determination of oleanic acid based on poly (sodium 4-styrenesulfonate-co-acrylic acid)-grafted multi-walled carbon nanotubes-chitosan and cobalt hexacyanoferrate nanoparticles," Biosensors \& bioelectronics, vol. 31, pp. 190-6, Jan 152012.

[38] Y. M. Yang, J. W. Wang, and R. X. Tan, "Immobilization of glucose oxidase on chitosan-SiO2 gel," Enzyme and microbial technology, vol. 34, pp. 126-131, 2004.

[39] K. Nawrotek, M. Tylman, K. Rudnicka, J. Gatkowska, and J. Balcerzak, "Tubular electrodeposition of chitosan-carbon nanotube implants enriched with calcium ions," Journal of the mechanical behavior of biomedical materials, vol. 60, pp. 256-266, Feb 112016.

40 [40] L. Sun, J. Liu, P. Zhang, Y. Meng, C. Liu, Y. Ma, Q. Xie, and W. Meng, "An amperometric biosensor and a biofuel cell of uric acid based on a chitosan/uricase-poly(furan-3-boronic acid)-Pd nanoparticles/plated Pd/multiwalled carbon nanotubes/Au electrode," Journal of Electroanalytical Chemistry, vol. 739, pp. 187-196, 2015.

[41] D. A. Shirley, "High-Resolution X-Ray Photoemission Spectrum of the Valence Bands of Gold," Phys. Rev. B vol. 5, p. 4709, 1972.

42 [42] J. H. Scofield, "Hartree-Slater subshell photoionization cross-sections at 1254 and 1487 eV," Journal of Electron Spectroscopy and Related Phenomena, vol. 8, pp. 129-137, 1976.

[43] L. Bokobza, J.-L. Bruneel, and M. Couzi, "Raman spectroscopy as a tool for the analysis of carbonbased materials (highly oriented pyrolitic graphite, multilayer graphene and multiwall carbon nanotubes) and of some of their elastomeric composites," Vibrational Spectroscopy, vol. 74, pp. 57-63, 2014.

[44] L. Zhou, M. Zhou, Z. Hu, Z. Bi, and K. G. Serrano, "Chemically modified graphite felt as an efficient cathode in electro-Fenton for p-nitrophenol degradation," Electrochimica Acta, vol. 140, pp. 376-383, 2014.

[45] D. J. Macquarrie and A. Bacheva, "Efficient subtilisin immobilization in chitosan, and peptide synthesis using chitosan-subtilisin biocatalytic films," Green Chemistry, vol. 10, p. 692, 2008.

[46] P. Ramirez, N. Mano, R. Andreu, T. Ruzgas, A. Heller, L. Gorton, and S. Shleev, "Direct electron transfer from graphite and functionalized gold electrodes to T1 and T2/T3 copper centers of bilirubin oxidase," Biochimica et biophysica acta, vol. 1777, pp. 1364-9, Oct 2008.

[47] M. Christwardana and Y. Kwon, "Effects of multiple polyaniline layers immobilized on carbon nanotube and glutaraldehyde on performance and stability of biofuel cell," Journal of Power Sources, vol. 299, pp. 604-610, 2015.

[48] Christophe Léger, Anne K. Jones, Simon P. J. Albracht, and F. A. Armstrong, "Effect of a Dispersion of Interfacial Electron Transfer Rates on Steady State Catalytic Electron Transport in [NiFe]-hydrogenase and Other Enzymes," J. Phys. Chem. B, vol. 106, pp. 13058-13063, 2002.

[49] S. Tsujimura, Y. Kamitaka, and K. Kano, "Diffusion-Controlled Oxygen Reduction on Multi-Copper Oxidase-Adsorbed Carbon Aerogel Electrodes without Mediator," Fuel Cells, vol. 7, pp. 463-469, 2007.

[50] S. El Ichi-Ribault, A. Zebda, A. Laaroussi, N. Reverdy-Bruas, D. Chaussy, M. N. Belgacem, A. L. Suherman, P. Cinquin, and D. K. Martin, "Laccase-based biocathodes: Comparison of chitosan and Nafion," Analytica chimica acta, vol. 937, pp. 43-52, Sep 212016.

51 [51] Gallifuoco A., D'Ercole L., Alfani F., Cantarella M., Spagna G., and P. P.G., "On the use of chitosanimmobilized-glucosidase in wine-making: kinetics and enzyme inhibition," Process Biochemistry, vol. 33, pp. 163-168, 1998.

[52] X. H. Xu, G. L. Ren, J. Cheng, Q. Liu, D. G. Li, and Q. Chen, "Layer by layer self-assembly immobilization of glucose oxidase onto chitosan-graft-polyaniline polymers," Journal of Materials Science, vol. 41, pp. 3147-3149, 2006. 

as electronic bridges for laccase-based biocathodes," Journal of the American Chemical Society, vol. 134, pp. 17212-20, Oct 172012. 